\title{
Restrictions of Constitutional Rights and Freedoms and Legal Obstacles in Their Implementation
}

\author{
Elena R. Zaitseva and Vladislav Yu. Panchenko* \\ Siberian Federal University \\ 79 Svobodny, Krasnoyarsk, 660041, Russia
}

Received 03.03.2015, received in revised form 12.05.2015, accepted 17.06.2015

The article is devoted to the ratio of restrictions of rights and freedoms and legal obstacles as the phenomena of legal life. It makes conclusions that the legal restrictions of rights and freedoms as a general rule cannot be regarded as legal obstacles; restrictions that do not meet the constitutional conditions of legality are legal obstacles that are surmountable judicially, while the judicial assessment is a judicially significant criterion of the difference between legal restrictions and obstacles.

Keywords: legal obstacles in realization of rights and freedoms, restrictions of rights and freedoms, rights and freedoms of man and citizen, constitutional law, legal regulation, theory of law.

The article was prepared with the financial support of the Russian Humanitarian Scientific Fund, project No. 14-33-01293.

DOI: 10.17516/1997-1370-2015-8-8-1576-1579.

Research area: law.

The whole complex of fundamental rights and freedoms enshrined in the Constitution of Russia can be divided into the rights and freedoms, the implementation of which does not require special regulation, and fundamental rights and freedoms that cannot do without a special law implementation mechanism to provide for them in the process of law-making and law enforcement activity. Realization of rights and freedoms of an individual is a procedural and legal mechanism for their implementation that is revealed through the order, structure (subjects, objects, the nature of connections between them), a variety of social and legal factors, forms, methods, conditions and guarantees for the implementation of the constitutional provisions in accordance with the democratic procedures, principles of legality and social justice ${ }^{1}$.

A category of juridical (legal) obstacles in the realization of rights and legitimate interests enables to determine, among all the circumstances that affect the process of the law implementation, the legal factors (conditions, circumstances) that block (fully or partially), hamper the implementation process of the legal opportunities

(C) Siberian Federal University. All rights reserved

* Corresponding author E-mail address: panchenkovlad@mail.ru 
(rights and legitimate interests), to identify them from the formally legal and content-social sides.

By their nature, legal obstacles in the realization of rights and legitimate interests can be either normatively established or judicially factual. They complicate the implementation of the legal opportunities (rights, freedoms and legitimate interests) of a specific subject of the right in a specific situation demanding that the carrier of the rights and legitimate interests should bear additional, normatively unprogrammed, or provided for by the established rules to implement rights, but disproportionate, unreasonable organizational, material and technical, temporal, intellectual and other costs ${ }^{2}$.

When considering the legal obstacles in realization of the constitutional rights and freedoms, we take legal obstacles as a research subject, but not the obstacles in law in general, i.e. the obstacles that are objective in relation to the subject of law and are generated not by social, economic and other conditions, but only by the law-making and law enforcement activity of the authorized subjects.

Normative legal obstacles are built into the law itself, into the legal and regulatory means. However, they can either be called as such or not be called obstacles at all. Legal obstacles are legal in a formal sense, i.e. are provided for by laws and other legal acts, acts of law enforcement, but are not legal from the standpoint of achieving the objectives of the legal regulation. Thus, according to the Constitutional Court of the Russian Federation, the absence of registration of an actual place of residence although is not an insurmountable obstacle to the implementation by a citizen of his own rights, in relation to particular rights and particular circumstances it can create inconvenience that requires additional efforts, which will entail restrictions on these rights that are disproportionate to constitutionally significant objectives ${ }^{3}$.
In the constitutional law the category of "obstacle in realization of rights and freedoms" is connected, first of all, with the category of "restriction of rights and freedoms of an individual."

It seems that "legal obstacles in realization of constitutional rights and freedoms" and "restrictions of constitutional rights and freedoms" are similar in form, but, in fact, they are different categories.

The restrictions of constitutional rights and freedoms are insurmountable at the given time in the territory of the given state, for they are set by this state, which, by virtue of its sovereignty, in each case gives priority to the public interest before the private interest. Restrictions are always established exclusively by the federal public authority or on its behalf, as only the federal public authority can reflect the public interest of the Russian Federation as a state fully and completely. Restrictions are always established openly stating the grounds of restrictions, their limits and a period of validity.

Firstly, the restrictions are set in specific articles of the Constitution of the Russian Federation that define the general principles of the restriction of constitutional rights and freedoms (Art. 55, 56 of the Constitution of the Russian Federation);

Secondly, the restrictions of rights may be provided in the constitutional clauses when one article of the Russian Constitution proclaims the right to anything and it also limits this right (the so-called clause in the law). Thus, providing the right to association the Constitution of the Russian Federation prohibits the establishment and activities of public associations pursuing the goals or actions directed toward a violent change of foundations of the constitutional order and violation of the integrity of the Russian Federation, undermining the security of the state, formation of armed groups, fomentation of social, 
racial, national and religious hatred (Art. 13); guaranteeing freedom of thought and expression does not accept propaganda or agitation inciting social, racial, national or religious hatred and hostility (Art. 29); giving citizens the right to elect and be elected to bodies of state power and local self-government authorities and to participate in a referendum, stipulates that those citizens who have been recognized as legally incapable by a court, as well as those held in places of deprivation of freedom by a court verdict do not have the right to elect and to be elected (Art. 32); giving everyone the right to freely use their abilities and property for entrepreneurial and other economic activity that is not prohibited by the law, does not allow the economic activity aimed at monopolization and unfair competition (Art. 34).

Thirdly, the restrictions are fixed in the regulatory acts, not below the level of the federal law. Thus, according to Art. 55 of the Russian Constitution, the rights and freedoms of man and citizen may be limited by the federal law only to the extent when it is necessary in order to protect the constitutional order, morality, health, rights and legal interests of other persons, safeguarding of national defence and state security. Moreover, in a state of emergency in order to ensure safety of citizens and protection of the constitutional system in accordance with the federal constitutional law specific restrictions on rights and freedoms with indication of the extent and term of their action may be established (Art. 56 of the Constitution of the Russian Federation).

Fourthly, in the decisions of the federal courts, according to the Constitution of the Russian Federation, those citizens who were recognized as legally incapable by a court, as well as those held in places of deprivation of freedom by a court verdict do not have the right to elect and to be elected (Art. 32). Restrictions on the right to privacy of correspondence, telephone conversations, postal, telegraph and other messages shall be allowed only by a court decision (Art. 23). Nobody has the right to enter the home, the inviolability of which is proclaimed, against the will of persons residing in it except in cases stipulated by the federal law or by a court decision (Art. 25). Everyone has the right to freedom and personal security, and the arrest, detention and holding in custody are allowed only by a court decision (Art. 22).

This shows that the restrictions imposed by the Constitution of the Russian Federation, federal laws and decisions of the federal courts are a kind of "withdrawal" from a man of the right in certain circumstances for a certain time in the territory of the Russian Federation.

Restrictions sort of "annul" the rights of a person at a given time and under the given circumstances. A person does not have a right as such. Therefore, restrictions that are established by the federal law and the decisions of the federal courts are objective within the given state. Another thing is that these restrictions can be recognized "excessive" or "discriminatory" by the international courts, the jurisdiction of which is recognized by the Russian Federation. Thus, the European Court of Human Rights recognized restrictions on human rights in the context of human health discriminatory, for example, when HIV status is used as the basis for differential treatment with regard to access to education, employment, health care, movement, social security, housing and asylum ${ }^{4}$.

According to the court, the provisions of Paragraph 2, Art. 3 and Paragraph 6, Art. 47 of the Federal Law dated July 11, 2001 No 95-FZ "On political parties" setting the requirements to be met by a political party, are not the excessive restriction on the right to association ${ }^{5}$.

Hence the ratio of categories of legal obstacles in realization of the constitutional rights and freedoms, and their restriction can be represented as follows: 1) restrictions on 
rights and freedoms meeting all constitutionally established requirements (Art. 55, 56 of the Constitution of the Russian Federation) by a general rule cannot be regarded as legal obstacles because they provide an existence framework of rights and freedoms themselves and are presumed as such limits of rights and freedoms before the moment of possible disqualification in the order of constitutional proceedings or suprastate judicial activity; 2) restrictions of rights and freedoms that do not meet constitutional terms of legality by the source of their entrenchment (that were not set at the level of federal legislation) are legal obstacles surmountable in civil, administrative or constitutional proceedings; 3) a legally significant criterion that distinguishes restrictions and legal obstacles and a mechanism that is able to "transfer" certain legal establishments into the rank of a particular category are the results of judicial activity of the appropriate level that cannot be reviewed in the framework of the legal system of the state.

See: L.D. Voevodin, The legal status of an individual in Russia. Tutorial. Moscow: MSU, Infra-M-Norma, 1997. 237 pp.

See: Panchenko V.Yu. On the concept of legal obstacles in the implementation and protection of rights and legitimate interests. Academic legal journal. 2013. No. 3. P. 14.

3 Decision of the Constitutional Court of the Russian Federation dated June 30, 2011 No 13-P "On the case on the constitutionality verification of the second paragraph of Article 1 of the Federal Law 'On Horticultural, Market-Gardening and Dacha Non-Commercial Associations of Citizens' in connection with the complaint of a citizen A. Vorobyov". From the reference and legal system ConsultantPlus.

4 See: Resolution of the European Court of Human Rights dated March 10, 2011. "Case 'Kiyutin against the Russian Federation”. Bulletin of the European Court of Human Rights. Russian edition. 2011. No. 12. P. 9, 104-121.

5 Resolution of the European Court of Human Rights on 12 April. 2011 «Business» Republican Party of Russia (Republican Party of Russia) against the Russian Federation «// Bulletin of the European Court of Human Rights. Russian edition. 2011. № 12. S. 9, 121-152.

\title{
Ограничения конституционных прав и свобод и юридические препятствия \\ в их реализации
}

\author{
Е.Р. Зайцева, В.Ю. Панченко \\ Сибирский федеральный университет \\ Россия, 660041, Красноярск, пр. Свободный, 79
}

\begin{abstract}
Статья посвящена соотношению ограничений прав и свобод и юридических препятствий как явлений правовой жизни. Обоснованы выводами о том, что законные ограничения прав и свобод по общему правилу не могут рассматриваться в качестве юридических препятствий; ограничения, не отвечаюшие конституционным условиям правомерности, являются юридическими препятствиями, преодолимыми в судебном порядке. При этом судебная оценка выступает юридически значимым критерием различия правовых ограничений и препятствий.

Ключевые слова: юридические препятствия в реализации прав и свобод, ограничения прав и свобод, права и свободы человека и гражданина, конституционное право, правовое регулирование, теория права.
\end{abstract}

Статья подготовлена при финансовой поддержке Российского гуманитарного научного фонда. Проект № 14-33-01293.

Научная специальность: 12.00.00 - юридические науки. 